Miscellaneous Publication 156

\title{
GEOSPATIAL DATABASE:
}

\section{Compiled Geologic Mapping in the Area of the Proposed Susitna-Watana Hydroelectric Project, South-central Alaska}

\author{
Mapping compiled by:
}

D.S.P. Stevens, E.N. Bachmann, and T.C. Wright

Bedrock compilation review and revision by:

D.N. Solie, Baseline Geoconsulting, LLC

\section{Published by}

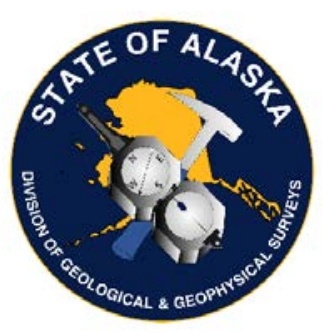

STATE OF ALASKA

DEPARTMENT OF NATURAL RESOURCES

DIVISION OF GEOLOGICAL \& GEOPHYSICAL SURVEYS

3354 College Road, Fairbanks, AK 99709-3707 • 907-451-5020

www.dggs.alaska.gov • dggspubs@alaska.gov

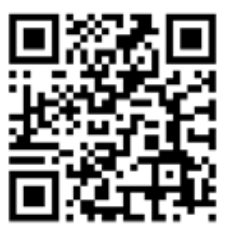





\title{
GEOSPATIAL DATABASE:
}

\section{Compiled Geologic Mapping in the Area of the Proposed Susitna-Watana Hydroelectric Project, South-central Alaska}

\author{
Mapping compiled by: \\ D.S.P. Stevens, E.N. Bachmann, and T.C. Wright \\ Bedrock compilation review and revision by: \\ D.N. Solie, Baseline Geoconsulting, LLC
}

\section{PROJECT SUMMARY}

The Alaska Energy Authority (AEA) in 2010 was authorized by the State of Alaska to begin laying the groundwork to develop the Susitna-Watana Hydroelectric Project on the Susitna River, Alaska. The project was intended to help meet the future electrical needs of Alaska's Railbelt Region by providing clean, renewable energy at the lowest possible long-term cost. An accurate assessment of the site geology is important for dam location, design, and construction, as well as for other planning and land management decisions in the region.

In support of the proposed Susitna-Watana Hydroelectric Project, the Alaska Division of Geological \& Geophysical Surveys (DGGS) developed a Geographic Information System (GIS)-based geologic compilation of published and unpublished maps for twelve, inch-to-mile (1:63,360-scale) quadrangles (fig. 1) encompassing the proposed hydroelectric project footprint, including the anticipated reservoir and surrounding area. DGGS geologists reviewed and analyzed existing geologic mapping for quality and completeness, and the maps were converted for use in GIS (table 1). The conversion process included scanning and georeferencing the original hard-copy map documents, creating a geodatabase, digitizing the geologic data, assigning attributes, and producing a digital data product for public release. The best available geologic mapping was synthesized into a single compilation data layer, and is packaged along with georeferenced scans and digitized vector files of the original geologic source maps. Bedrock geology was reviewed and revised by an independent contractor to ensure consistency with current geologic interpretations of the area.

This geodatabase product will be a valuable reference resource for developers, planners, and scientists working on the hydroelectric project, as well as for any other projects in the area.

\section{ACKNOWLEDGMENTS}

This capital project was funded by the Alaska Energy Authority (AEA) through the Alaska Department of Commerce, Community, and Economic Development (DCCED). 
Table 1. Data Sources for Geologic Map Compilation, Proposed Susitna-Watana Hydroelectric Project

\begin{tabular}{|c|c|}
\hline DAS01 & $\begin{array}{l}\text { Kline, J.T., Bundtzen, T.K., and Smith, T.E., 1990, Preliminary bedrock geologic map of the Talkeetna } \\
\text { Mountains D-2 Quadrangle, Alaska: Alaska Division of Geological \& Geophysical Surveys Public Data File } \\
\text { 90-24, } 13 \text { p., } 1 \text { sheet, scale 1:63,360. doi:10.14509/1458 }\end{array}$ \\
\hline DAS02 & $\begin{array}{l}\text { Smith, T.E., Albanese, M.D., and Kline, G.L., 1988, Geologic map of the Healy A-2 Quadrangle, Alaska: } \\
\text { Alaska Division of Geological \& Geophysical Surveys Professional Report 95, } 1 \text { sheet, scale 1:63,360. } \\
\text { doi: } \underline{10.14509 / 2276}\end{array}$ \\
\hline DAS03 & $\begin{array}{l}\text { Csejtey, Béla, Jr., Nelson, W.H., Jones, D.L., Silberling, N.J., Dean, R.M., Morris, M.S., Lanphere, M.A., } \\
\text { Smith, J.G., and Silberman, M.L., 1978, Reconnaissance geologic map and geochronology, Talkeetna } \\
\text { Mountains Quadrangle, northern part of Anchorage Quadrangle, and southwest corner of Healy Quadrangle, } \\
\text { Alaska: U.S. Geological Survey Open-File Report 78-558-A, } 60 \text { p., } 1 \text { sheet, scale 1:250,000. } \\
\text { http://dggs.alaska.gov/pubs/id/12425 }\end{array}$ \\
\hline DAS04 & $\begin{array}{l}\text { Reger, R.D., Bundtzen, T.K., and Smith, T.E., 1990, Geology of the Healy A-3 Quadrangle, Alaska: Alaska } \\
\text { Division of Geological \& Geophysical Surveys Public Data File 90-1, } 13 \text { p., } 2 \text { sheets, scale 1:63,360. } \\
\text { doi:10.14509/1433 }\end{array}$ \\
\hline DAS05 & $\begin{array}{l}\text { Clautice, K.H., 1990, Geologic map of the Valdez Creek mining district: Alaska Division of Geological \& } \\
\text { Geophysical Surveys Public Data File 90-30, } 1 \text { sheet, scale 1:250,000. doi:10.14509/1464 }\end{array}$ \\
\hline $\begin{array}{l}\text { DAS06- } \\
\text { DAS21 }\end{array}$ & $\begin{array}{l}\text { Acres, 1982a, Susitna Hydroelectric Project: 1980-81 Geotechnical Report, v. 2, part 2, Appendix G-K, final } \\
\text { draft, } 237 \text { p. http://www.arlis.org/docs/vol1/Susitna/0/APA69.html }\end{array}$ \\
\hline DAS22 & $\begin{array}{l}\text { Woodward-Clyde Consultants, 1982, Final report on seismic studies for Susitna Hydroelectric Project, } 363 \text { p. } \\
\text { (fig. 3-4). http://www.arlis.org/docs/vol1/Susitna/12/APA1255.pdf }\end{array}$ \\
\hline DAS23 & $\begin{array}{l}\text { Woodward-Clyde Consultants, 1982, Final report on seismic studies for Susitna Hydroelectric Project, } 363 \text { p. } \\
\text { (fig. 4-15). http://www.arlis.org/docs/vol1/Susitna/12/APA1255.pdf }\end{array}$ \\
\hline DAS24 & $\begin{array}{l}\text { Merritt, R.D., Eakins, G.R., and Clough, J.G., 1982, Coal investigation of the Susitna Lowland: Alaska Division } \\
\text { of Geological \& Geophysical Surveys Alaska Open-File Report 142, } 89 \text { p., } 4 \text { sheets, scale 1:250,000. } \\
\text { doi:10.14509/62 }\end{array}$ \\
\hline DAS25 & $\begin{array}{l}\text { Eakins, G.R., Jones, B.K., and Forbes, R.B., 1977, Investigation of Alaska’s uranium potential: Alaska Division } \\
\text { of Geological \& Geophysical Surveys Alaska Open-File Report 109, } 213 \text { p., } 10 \text { sheets, scale 1:250,000. } \\
\text { doi:10.14509/21 }\end{array}$ \\
\hline DAS26 & $\begin{array}{l}\text { Csejtey, Béla, Jr., 1974, Reconnaissance geologic investigations in the Talkeetna Mountains, Alaska: U.S. } \\
\text { Geological Survey Open-File Report 74-147, } 48 \text { p., } 1 \text { sheet, scale 1:63,360. } \\
\text { http://dggs.alaska.gov/pubs/id/11004 }\end{array}$ \\
\hline $\begin{array}{l}\text { DAS27- } \\
\text { DAS28 }\end{array}$ & $\begin{array}{l}\text { Acres, 1982b, Susitna Hydroelectric Project, } 1982 \text { Supplement to 1980-81 Geotechnical Report. } \\
\text { http://www.arlis.org/docs/vol1/Susitna/0/APA68.html }\end{array}$ \\
\hline DAS29 & $\begin{array}{l}\text { Richter, D.H., 1963, Geology of the Portage Creek-Susitna River area: Alaska Division of Mines and Minerals } \\
\text { Geologic Report 3, } 2 \text { sheets, scale 1:24,000. doi:10.14509/332 }\end{array}$ \\
\hline DAS30 & $\begin{array}{l}\text { Woodward-Clyde Consultants, 1982, Final report on seismic studies for Susitna Hydroelectric Project, } 363 \text { p. } \\
\text { (fig. 4-21). http://www.arlis.org/docs/vol1/Susitna/12/APA1255.pdf }\end{array}$ \\
\hline DAS31 & $\begin{array}{l}\text { Csejtey, Béla, Jr., Mullen, M.W., Cox, D.P., and Stricker, G.D., 1992, Geology and geochronology of the Healy } \\
\text { Quadrangle, south-central Alaska: U.S. Geological Survey Miscellaneous Investigations Series Map 1961, } 63 \\
\text { p., } 2 \text { sheets, scale 1:250,000. http://dggs.alaska.gov/pubs/id/12847 }\end{array}$ \\
\hline DAS33 & $\begin{array}{l}\text { Clautice, K.H., Newberry, R.J., Pinney, D.S., Blodgett, R.B., Bundtzen, T.K., Gage, B.G., Harris, E.E., Liss, } \\
\text { S.A., Miller, M.L., Reifenstuhl, R.R., and Clough, J.G., 2001, Geologic map of the Chulitna region, } \\
\text { southcentral Alaska: Alaska Division of Geological \& Geophysical Surveys Report of Investigation 2001- } \\
\text { 1B, } 32 \text { p., } 1 \text { sheet, scale 1:63,360. doi: } \underline{10.14509 / 2771}\end{array}$ \\
\hline DAS34 & $\begin{array}{l}\text { Woodward-Clyde Consultants, 1982, Final report on seismic studies for Susitna Hydroelectric Project, } 363 \text { p. } \\
\text { (fig. 4-17). http://www.arlis.org/docs/vol1/Susitna/12/APA1255.pdf }\end{array}$ \\
\hline
\end{tabular}




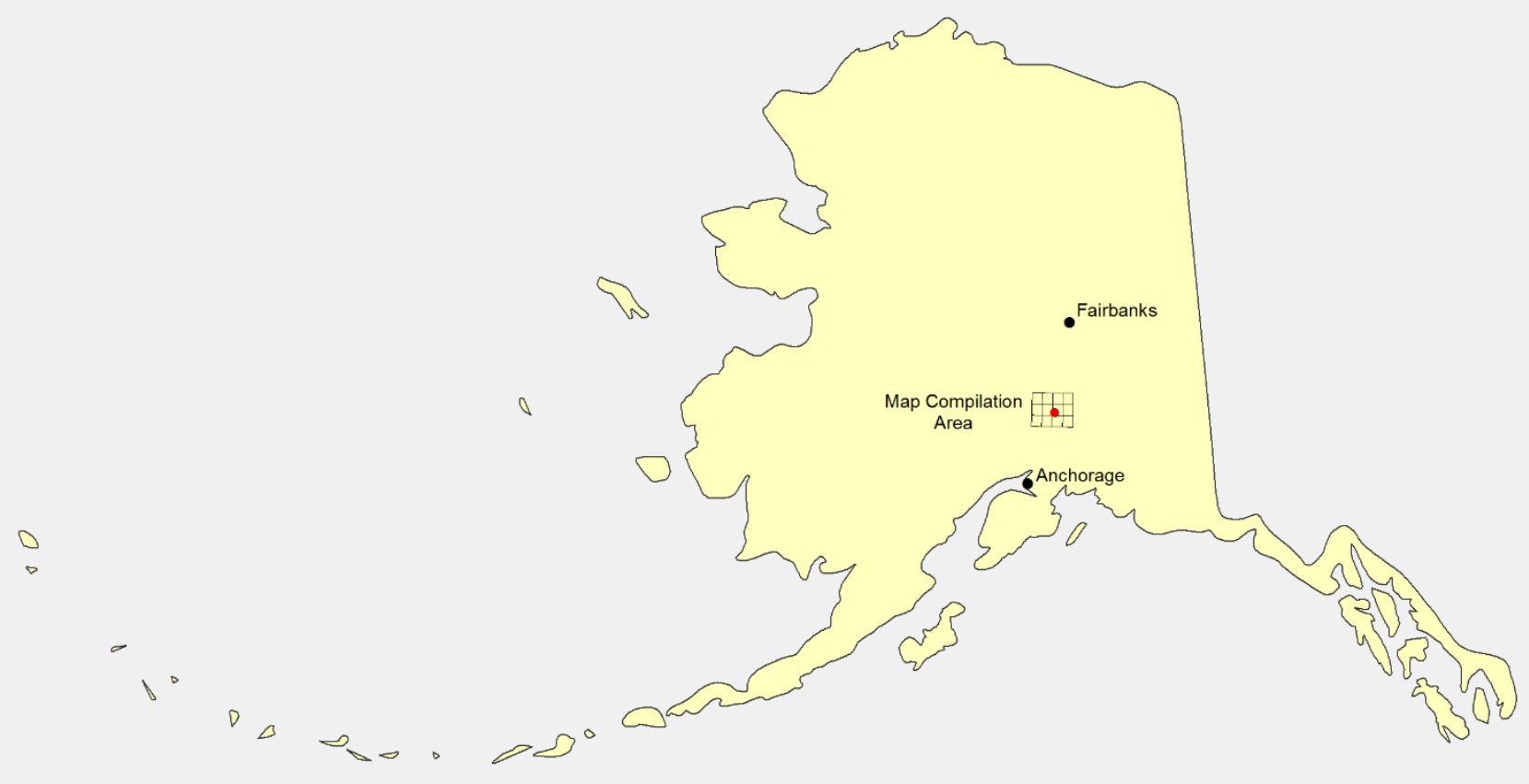

Figure 1. Map showing 1:63,360-scale quadrangles included in the geologic map compilation geodatabase: Healy A-2, A-3, A-4, A-5; and Talkeetna Mountains C-2, C-3, C-4, C-5, D-2, D-3, D-4, D-5. Red dot is location of the proposed dam and powerhouse. 